
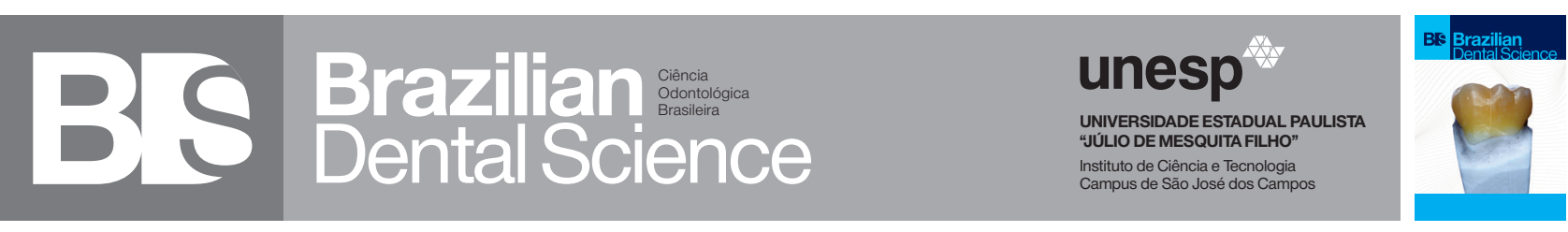

\title{
Antimicrobial activity of various brands of children's toothpastes formulated with Triclosan, fluoride and xylitol
}

Atividade antimicrobiana de dentifrícios infantis formulados com Triclosan, xylitol e fluoreto, disponíveis no mercado Leopoldo COSME-SILVA ${ }^{1}$, Ana Paula Pereira da SILVEIRA ${ }^{1}$, Kellen Cristina da Silva GASQUE ${ }^{3}$, Rafael Tobias MORETTI-NETO ${ }^{1}$, Vivien Thiemy SAKAI ${ }^{1}$, Jorge Kleber CHAVASCO$^{2}$, Ana Beatriz da Silveira MORETTI ${ }^{1}$

1 - Department of Clinics and Surgery - School of Dentistry - Federal University of Alfenas - Alfenas - MG - Brazil.

2 - Department of Microbiology and Immunology - Institute of Biomedical Sciences - Federal University of Alfenas - Alfenas - MG - Brazil.

3 - Program of Dental Sciences - School of Dentistry - Federal University of Alfenas - Alfenas - MG - Brazil.

\section{ABSTRACT}

Objective: Evaluate and compare the antimicrobial efficacy of four different commercially available children's toothpastes on bacteria growth inhibition from oral microbiota of young children. Material and Method: The toothpastes tested contained: $1100 \mathrm{ppm}$ sodium fluoride, xylitol and $750 \mathrm{ppm}$ sodium fluoride, xylitol and $500 \mathrm{ppm}$ sodium fluoride, and xylitol and triclosan. Twenty 18 to 36 month-old children were selected. Nonstimulated saliva samples were collected and inoculated on brain heart infusion (BHI) agar. Toothpaste dilutions were applied into the agar wells and incubated at 37 ${ }^{\circ} \mathrm{C}$ for 24 hours in microaerophilic conditions. Saline and $0.12 \%$ chlorhexidine were used as controls. Antimicrobial activity was determined in duplicate by agar-well diffusion technique. Bacterial growth inhibition zones were recorded in mm. Statistical analysis was performed using ANOVA and Tukey's test $(\mathrm{p}<0.05)$. Results: All toothpastes showed antimicrobial activity when compared to negative control ( $<$ 0.05). Toothpaste containing triclosan presented the highest antimicrobial activity followed, in this order, by xylitol and $750 \mathrm{ppm}$ sodium fluoride, chlorhexidine, $1100 \mathrm{ppm}$ sodium fluoride, xylitol and $500 \mathrm{ppm}$ sodium fluoride and saline. Conclusion: Toothpaste containing triclosan and xylitol presented excellent antimicrobial activity, and may be considered a good option for young children.

\section{KEYWORDS}

Toothpastes; Oral hygiene; Pediatric Dentistry.

\section{RESUMO}

Objetivo: Avaliar e comparar a atividade antimicrobiana de 4 dentifrícios infantis, comercialmente disponíveis, com relação à inibição do crescimento da microbiota oral em crianças. Material e Métodos: Os dentifrícios testados continham: 1100 ppm de fluoreto de sódio - xilitol e 750 ppm de fluoreto de sódio - xilitol e 500 ppm de fluoreto de sódio - xilitol e triclosan. Vinte crianças de 18 a 36 meses participaram dessa pesquisa. Amostras de saliva não estimulada foram coletadas e inoculadas em ágar de infusão cérebro-coração (ICC). Dentifrícios diluídos foram aplicados sobre os poços contendo ICC e incubados a $37^{\circ} \mathrm{C}$ por 24 horas em condições microaerofilicas. Solução salina e clorexidina a $0,12 \%$ foram usadas como controles. A atividade antimicrobiana foi determinada em duplicata pela técnica de difusão nos poços de ágar. Os halos de inibição do crescimento bacteriano foram registrados em $\mathrm{mm}$. A análise estatística foi realizada usando ANOVA e teste de Tukey $(\mathrm{p}<0,05)$. Resultados: Todos os dentifrícios mostraram atividade antimicrobiana, quando comparados com os controles negativos. O dentifrício contendo triclosan mostrou a maior atividade antimicrobiana, seguido, nessa ordem por dentifrício contendo xilitol e 750 ppm de fluoreto de sódio, clorexidina, dentifrício contendo 1100 ppm de fluoreto de sódio, dentifrício contendo xilitol e 500 ppm de fluoreto de sódio e pela solução salina. Conclusão: $\mathrm{O}$ dentifrício contendo triclosan e xylitol apresentou excelente atividade antimicrobiana podendo ser considerado uma vantajosa opção para crianças, contribuindo para o controle das cáries dentárias e reduzindo a ingestão de fluoretos.

\section{PALAVRAS-CHAVE}

Dentifrícios; Higiene oral; Odontopediatria. 


\section{INTRODUCTION}

$\mathrm{T}$ ooth decay affects between $60-90 \%$ of school children, which turn it into a public health problem $[1,2]$. Research has been conducted in order to assess the natural and synthetic chemical agents that could act as a coadjutant to the effect of mechanical tooth brushing on dental caries control $[1,3]$. Among these chemicals, toothpastes are considered the main aid agents. Typically, they consist of therapeutic, abrasives, detergents, flavoring agents, pigments, thickening agents and humectants, and each of them has a specific role in bacterial adhesion and proliferation control and/or also in remineralization of the tooth structure [4].

A broad range of toothpastes are available in the market. Manufacturers offer colored and flavored toothpastes, signed by famous figures, to make them attractive for children $[5,6]$. The presence of fluoride in toothpaste used by children is widely discussed in the literature, because of the risk of swallowing the paste, thus increasing the risk of dental fluorosis [5,7]. The use of toothpastes containing 1,000 ppm of fluoride is endorsed by the American Academy of Pediatric Dentistry, regardless of the child's age, as a primary preventive procedure. On the other hand, the European Pediatric Dentistry Academy recommends the use of toothpastes formulated with 500, 1,000 and 1,500 ppm of fluoride to children aged from 6 months to 2 years old, 2 to 6 years old and older than 6 years old, respectively [8].

Although several toothpastes indicated for oral hygiene of infants and children are available in the market, many dentists are unaware of their effect on cariogenic microbiota. It is mandatory that children's toothpastes pass the scrutiny of antimicrobial activity, thus allowing professionals to consciously make better clinical decisions, indicating these products to their patients. With that in mind, the purpose of the present work was to evaluate and compare the antimicrobial activity of four commercially available children's toothpastes on the bacterial growth of oral microbiota from young children.

\section{MATERIAL AND METHODS}

The Ethics Committee of Federal University of Alfenas approved the protocol for this study (protocol \#093/2010). Prior to the sample collection, informed consent was obtained from the parents or guardians of 20 children aged between 18 and 36 months, who attended a day care center. Children presenting tooth decay and those who had received antibiotics in the previous two weeks were excluded from the study.

Four toothpastes for children marketed in Brazil were investigated: toothpaste A: $1100 \mathrm{ppm}$ sodium fluoride (Colgate Smiles Barbie ${ }^{\circledR}$-Colgate Palmolive Ind Com Ltda - São Bernardo do Campo, SP, Brazil); toothpaste B: $750 \mathrm{ppm}$ sodium fluoride and xylitol (Ben10® -Bitufo Mont and with brushes Ltda - Itupeva, SP, Brazil); toothpaste C: mallow extract, $500 \mathrm{ppm}$ sodium fluoride and xylitol (Malvatrikids F infantil@ - Bitufo Mont e Com Ltda -Itupeva brushes, SP, Brazil) and toothpaste D: triclosan and xylitol (Cocoricó ${ }^{\circledR}$ - Bitufo Mont Ltda - Itupeva, SP, Brazil). Toothpastes components, as demonstrates by the manufacturers, are shown in Table 1. 
Table 1 - Ingredients of toothpastes tested for antimicrobial potential, as displayed on their commercial packages. (A) Colgate Smiles Barbie ${ }^{\circledR}$ (Colgate Palmolive Ind. Com. Ltda - Brazil); (B) Ben10 ${ }^{\circledR}$ (Bitufo Mont. e Com. de Escovas Ltda Brazil); (C) Malvatrikids F infanti ${ }^{\otimes}$ (Laboratório Daudt Oliveira Ltda - Brazil); and (D) Cocoricó ${ }^{\circledR}$ (Bitufo Mont. e Com. de Escovas Ltda - Brazil)

\begin{tabular}{|c|c|c|c|c|}
\hline \multirow{2}{*}{ Ingredients } & \multicolumn{4}{|c|}{ Toothpastes } \\
\hline & A & B & C & D \\
\hline Agar & & $X$ & & \\
\hline Alcohol & & & & $x$ \\
\hline Aroma & $X$ & $x$ & $x$ & $x$ \\
\hline Carboxymetilcellulose & $x$ & & & \\
\hline Cellulose gum & & $x$ & $x$ & $x$ \\
\hline EDTA & & & & $X$ \\
\hline Flavor & $X$ & $x$ & & $X$ \\
\hline Gycerin & & $x$ & $x$ & $x$ \\
\hline Hydrated silica & $x$ & $x$ & $x$ & $X$ \\
\hline Mallow extract & & & $x$ & \\
\hline Menthol & & $x$ & & \\
\hline Methylparaben & & & & $X$ \\
\hline Pigment & $x$ & $x$ & $x$ & $x$ \\
\hline Polyethylene glycol 8 & & $x$ & & $x$ \\
\hline Polyethylene glycol 12 & $X$ & & & \\
\hline Polyethylene glycol 600 & $X$ & & & \\
\hline Saccharine & $X$ & $x$ & & $x$ \\
\hline Sodium benzoate & & & $x$ & \\
\hline Sodium fluoride (500 ppm) & & & $x$ & \\
\hline Sodium fluoride (750 ppm) & & $x$ & & \\
\hline Sodium fluoride (1100 ppm) & $x$ & & & \\
\hline Sodium lauryl sulfate & $x$ & $x$ & $x$ & $x$ \\
\hline Sorbitol & $x$ & $x$ & $x$ & $x$ \\
\hline Titanium dioxide & $x$ & & & \\
\hline Titanium hydroxide & & & & $x$ \\
\hline Triclosan & & & & $x$ \\
\hline Water & $x$ & $x$ & $x$ & $x$ \\
\hline Xhantan gum & & & & $X$ \\
\hline Xylitol & & $x$ & $x$ & $x$ \\
\hline
\end{tabular}

Total spontaneous saliva of 20 children was collected by moistened sterile swabs with saline solution from the mucosal lining of the buccal cavity two hours after feeding without brushing, as described by Modesto et al [9]. The swabs were inoculated on brain heart infusion (BHI) agar, in which one central and six wells at equidistance in each plate were prepared using a sterile 4-mm cork borer. Toothpaste solutions were diluted in saline at a final concentration of $50 \%(\mathrm{w} / \mathrm{v})$ and applied into the wells. Saline (E) and $0.12 \%$ chlorhexidine (F) were used as negative and positive controls, respectively. Plates were incubated at $37{ }^{\circ} \mathrm{C}$ for 24 hours in microaerophilic conditions. The antimicrobial activity was determined in duplicate by agarwell diffusion technique $[10,11]$. The bacterial growth inhibition zones were recorded in $\mathrm{mm}$. A statistical analysis was performed using analysis of variance (ANOVA) followed by Tukey's test in the GraphPad Prism software, with $\mathrm{p}$ values $<0.05$ considered significant.

\section{RESULTS}

Table 2 presents the means and standard deviations of growth inhibition zones of the children's toothpastes tested in the present study. Toothpaste D presented the highest antimicrobial activity followed by toothpaste $\mathrm{B}$, the positive control, toothpaste A, toothpaste $\mathrm{C}$ and the negative control, which did not inhibit the growth of microorganisms.

Table 2 - Average diameter of growth inhibition zones (in mm) of different children's toothpastes against microorganisms of young children total saliva $(n=20)$. (A) Colgate Smiles Barbie ${ }^{\circledR}$; (B) Ben10 ${ }^{\circledR}$; (C) Malvatrikids F infanti ${ }^{\circledR}$; (D) Cocoricó ${ }^{\circledR}$; (E) Saline negative control; and (F) 0.12\% clhorhexidine - positive control

\begin{tabular}{|ccc|}
\hline Toothpastes and Controls & Mean & Standard Deviation \\
\hline A & $10.58^{\mathrm{a}}$ & 4.04 \\
\hline B & $13.10^{\mathrm{a}}$ & 4.99 \\
\hline C & $5.25^{\mathrm{b}}$ & 4.03 \\
\hline D & $15.75^{\mathrm{c}}$ & 3.99 \\
\hline E & $0.00^{\mathrm{d}}$ & 0.00 \\
\hline F & $11.40^{\mathrm{a}}$ & 2.01 \\
\hline
\end{tabular}

Different upper letter mean significant statistical difference. 


\section{DISCUSSION}

The control of oral biofilms by mechanical removal is essential for maintaining oral health, but the use of antimicrobial agents has also been reported to be a good adjuvant in the chemical control of the biofilm [12,13]. Antimicrobial activity of different chemical agents in toothpastes have been demonstrated, helping in the control of pathogenic microflora $[12,14]$. Toothpastes analyzed in this study contain different fluoride concentrations and antimicrobial products such as xylitol (in toothpastes B, C and D), mallow extract (Toothpaste $\mathrm{C}$ ) or triclosan (Toothpaste D). These substances are included in the formulation to control Streptococcus mutans proliferation [14].

The effectiveness of fluoride on tooth remineralization is well established in the literature $[12,15,16]$ as wells as its risk of fluorosis when excessive fluoride intake occurs $[12,17]$. However, there is no consensus about fluoride's effectiveness against cariogenic bacteria growth or proliferation [18-22]. It is known that under conditions of low $\mathrm{pH}$, fluoride has a greater capacity to bind to the structures of the bacterial surface, decreasing the action of these pathogens [23].

Antimicrobial activity of fluoride have been shown elsewhere [22]. However, in our study, toothpastes containing fluoride (B and C) presented smaller zones of inhibition of bacterial growth than the non-fluoridated toothpaste (D). In this study, the low antibacterial power of fluoride-containing toothpastes may be related to the agar medium used that holds the medium around $\mathrm{pH} 7.4$ (neutral), which reduces fluoride ability to bind on bacteria, as reported before [22].

Xilitol, contained in toothpastes B, C, D, is able to reduce levels of mutans streptococci in plaque and saliva by disrupting the energy production process of $S$. mutans, leading to a blockage of energy production and consequently cell death [6]. In addition, it reduces the adhesion of these microorganisms to the surface of the teeth and the production of acids. Triclosan, another antibacterial agent in the composition of toothpaste $\mathrm{D}$, causes bacterial wall disruption, as it inhibits the enoylacyl reductase protein that is essential for the synthesis of fatty acids present in the bacterial membrane. In the absence of fatty acids, cell death occurs [24]. In this study, toothpaste D achieved greater antimicrobial activity. The association of xylitol and triclosan leads to a synergistic effect [24], which may explain the higher antibacterial action of the toothpaste D. Toothpastes with triclosan showed higher antimicrobial activity $[10,22]$, corroborating our results and suggesting that the incorporation of triclosan in the toothpaste for children is beneficial since it can reduce the risk of caries.

Besides xylitol, the toothpaste C contain mallow extract, which has antimicrobial properties [25]. However, among the investigated toothpastes, formulation $\mathrm{C}$ was less effective in inhibiting microbial against salivary children's microorganisms, possibly because effects of herbal extracts only occur when stimulated by the immune system, therefore

requiring in vivo studies [25].

\section{CONCLUSION}

Considering the methodology of this research, all tested toothpastes had some antimicrobial activity. Toothpaste containing triclosan and xylitol presented an excellent antimicrobial activity, and may be considered a good option for young children since it may reduce the risk for dental caries, as well as decrease children's exposure to fluoride.

\section{funding}

Conflict of interest and sources of

The authors declare that there is no conflict of interest regarding the publication of this article. 


\section{REFERENCES}

1. Petersen PE The The World Oral Health Report2003: continuous improvement of oral health in the 21st century--the approach of the WHO Global Oral Health Programme. Community Dent Oral Epidemiol. 2003 Dec;31Suppl 1:3-23.

2. Rubido S, Fernández-Feijoo J, Limeres J, García-Caballero L, Abeleira MT, Diz P.In vivo antiplaque effect of three edible toothpastes. Med Oral Patol Oral Cir Bucal. 2014 Jan 1;19(1):e88-92.

3. Nandlal B, Shahikumar P,Avinash BS, Sreenivasan PK, Subramanyam R. Malodor reductions and improved oral hygiene by toothbrushing and mouthrinsing. Indian J Dent Res. 2016 Jan-Feb;27(1):42-7.doi:10.4103/09709290.179815.

4. Cury JA, Tenuta LM. Evidence-based recommendation on toothpaste use. Braz Oral Res. 2014;28 Spec No:1-7.doi:101590/S1806-83242014.50000001.

5. Dos Santos AP,Nadanovsky P,De Oliveira BH. Inconsistencies in recommendations on oral hygiene practices for children by professional dental and paediatric organisations in ten countries. Int J Paediatr Dent. 2011 May;21(3):223-31. doi: 10.1111/j.1365-263X.2011.01115.x. Epub2011 Feb 20..

6. Lima YBO, Cury JA. Seasonal variation of fluoride intake by children ina subtropical region. Caries Res. 2003 Sep-0ct;37(5):335-8.

7. ZohooriFV, Duckworth RM, Omid N, O'Hare WT,Maguire A. Fluoridated toothpaste: usage and ingestion of fluoride by 4- to 6-year-old children in England. Eur J Oral Sci. 20120ct;120(5):415-21. doi:10.1111/j.16000722.2012.00984.x. Epub2012 Aug 6.

8. Giacaman RA, Carrera CA, Muñoz-Sandoval C, Fernandez C, Cury JA. Fluoride content in toothpastes commercialized for children in Chile and discussion on professional recommendations of use. Int J Paediatr Dent. 2013 Mar;23(2):7783. doi:10.1111/.1365-263X.2012.01226.x. Epub2012Feb 9.

9. Modesto A, Lima KC, de Uzeda M. Effects of three different infant dentifrices on biofilms and oral microorganisms. J Clin Pediatr Dent. 2000 Spring;24(3):237-43.

10. Prasanth M. Antimicrobial efficacy of different toothpastes and mouthrinses: an in vitro study. Dent Res J (Isfahan). 2011 Spring;8(2):85-94.

11. Verkaik MJ, Busscher HJ, Jager D, Slomp AM, Abbas F, van der Mei HC. Efficacy of natural antimicrobials in toothpaste formulations against oral biofilms in vitro. J Dent. 2011 Mar;39(3):218-24. doi: 10.1016/j.jdent.2010.12.007. Epub 2010 Dec 30.

12. de Camargo Smolarek P,Esmerino LA, Chibinski AC, Bortoluzzi MC, Dos Santos $E B$, Kozlowski VA Junior. In vitro antimicrobial evaluation of toothpastes with natural compounds. Eur J Dent. 2015 Oct-Dec;9(4):580-6. doi: 10.4103/13057456.172632 .
13. Fine DH, Furgang D, Markowitz K, Sreenivasan PK, Klimpel K, Vizio DW. The antimicrobial effect of a triclosan/copolymer dentifrice on oral microorganisms in vivo. J Am Dent Assoc. 2006 0ct;137(10):1406-13.

14. Anushree B, Fawaz MA, Narahari R, Shahela T,Syed A. Comparison of antimicrobial efficacy of triclosan- containing, herbal and homeopathy toothpastes- an invitro study. J Clin Diagn Res. 2015 0ct;9(10):DC05-8. doi: 10.7860/JCDR/2015/11984.6626. Epub 2015 0ct1.

15. Marinho VCC, Higgins JPT, Sheiham A, Logan S. Fluoride toothpastes for preventing dental caries in children and adolescents. Cochrane Database Syst Rev 2016 Jul;29:7 CD002284.

16. Randall JP,Seow WK, Walsh LJ. Antibacterial activity of fluoride compounds and herbal toothpastes on Streptococcus mutans: an in vitro study. Aust Dent J. 2015Sep;60(3):368-74. doi:10.1111/adj.12247.

17. Azevedo MS, Goettems ML, Torriani DD, Demarco FF.Factors associated with dental fluorosis in school children in southern Brazil: a cross-sectional study. Braz Oral Res 2014 May;28. pii:S1806-83242014000100225. Epub 2014 May 16.

18. Stoodley P,Wefel J, Gieseke A, Debeer D, von Ohle C. Biofilm plaque and hydrodynamic effects on mass transfer, fluoride delivery and caries. J Am Dent Assoc. 2008 Sep;139(9):1182-90.

19. Koo H. Strategies to enhance the biological effects of fluoride on dental biofilms. Adv Dent Res. 2008 Jul 1;20(1):17-21.

20. Wong MC, Clarkson J, Glenny AM, Lo EC, Marinho VC, Tsang BW, etal. Cochrane reviews on the benefits/risks of fluoride toothpastes. J Dent Res. 2011 May;90(5):573-9. doi: 10.1177/0022034510393346. Epub 2011 Jan 19.

21. Ten Cate JM, Van Loveren C. Fluoride mechanisms. Dent Clin North Am. 1999 0ct:43(4):713-42, vii.

22. Evans A, Leishman SJ, Walsh LJ, Seow WK. Inhibitory effects of children's toothpastes on Streptococcus mutans, Streptococcus sanguinis and Lactobacillus acidophilus. Eur Arch Paediatr Dent. 2015 Apr;16(2):219-26. doi: 10.1007/s40368-014-0159-3. Epub 2014 Nov 18.

23. Marquis RE, Clock SA, Mota-Meira M. Fluoride and organic weak acids as modulators of microbial physiology. FEMS Microbiol Rev. 2003 Jan;26(5):493510 .

24. Heath RJ, Rubin JR, Holland DR, Zhang E, Snow ME, Rock CO. Mechanism of triclosan inhibition of bacterial fatty acid synthesis. J Biol Chem. 1999 Apr 16;274(16):11110-4.

25. Fatima S, Faroogi AHA, Kumar R, Kumar TRS, Khanuja SPS. Antibacteria activity possessed by medicinal plants used in tooth powders. J Med Aromatic Plant Sci 2001;22:187-9.

\section{Dra . Ana Beatriz Silveira Moretti}

(Corresponding address)

Departament of Clinics and Surgery

School of Dentistry, Alfenas Federal University

Rua Gabriel Monteiro da Silva, 700, Centro, Alfenas, MG, Brazil.

CEP: 37130-000.

Date submitted: 2019 Feb 20

e-mail: ana.moretti@unifal-mg.edu.br
Accept submission: 2019 May 10 